\title{
Sensory quality and economics of preparation of karonda candy
}

- RASHMI PATIL *, V.U. RAUT ${ }^{1}$ AND R.S. WANKHADE

University Department of Horticulture, Dr. Panjabrao Deshmukh Krishi Vidyapeeth, AKOLA (M.S.) INDIA (Email: patilrashu03@gmail.com, wankhade_r@rediffmail.com)

${ }^{1}$ Department of Horticulture, College of Agriculture, NAGPUR (M.S.) INDIA

*Author for Correspondence

Research chronicle : Received : 14.07.2014; Revised : 10.11.2014; Accepted : 25.11.2014

\section{SUMMARY :}

The study on sensory quality and economics of preparation of karonda candy was carried out during the year 2012-2013 at Post Harvest Technology Laboratory, Department of Horticulture, Post Graduate Institute, Dr. Panjabrao Deshmukh Krishi Vidyapeeth, Akola. An experiment was laid out in Factorial Completely Randomized Design with seven treatments and three replications with 14 treatment combinations. From the findings in sensory qualities of candy, the overall scores of taste and colour found to decrease in trend with the advancement of storage an interval of 30 days. The karonda candy recorded more acceptable score in cabinet drying than the solar drying. However, the treatment combination $\mathrm{T}_{1} \mathrm{D}_{1}$ (Fruit pieces impregnated with cane sugar (TSS 60 ${ }^{\circ}$ Brix) $+0.5 \%$ citric acid + cabinet drying) and $\mathrm{T}_{1} \mathrm{D}_{2}$ (Fruit pieces impregnated with cane sugar (TSS $\left.60^{\circ} \mathrm{Brix}\right)+0.5 \%$ citric acid + solar drying) recorded the maximum score at cabinet and solar drying, respectively. Considering the economics of the best acceptable recipe, the candy prepared with the combination of fruit pieces impregnated with cane sugar (TSS $60^{\circ}$ Brix) $+0.5 \%$ citric acid + solar drying was found economical as compared to the other treatment combinations (Recipes) dried in cabinet drying.

KEY WORDS : Sensory quality, Economics, Karonda candy

How to cite this paper : Patil, Rashmi, Raut, V.U. and Wankhade, R.S. (2014). Sensory quality and economics of preparation of karonda candy. Internat. J. Proc. \& Post Harvest Technol., 5 (2) : 169-172. 